\title{
WHY DO ECONOMICS NEED "ITS HIGGS FIELD"? (English translated version)
}

\author{
¿POR QUÉ LA ECONOMÍA NECESITA "SU CAMPO DE HIGGS"?
}

\section{POR QUE A ECONOMIA PRECISA DE "SEU CAMPO DE HIGGS"?}

\section{Henry Mora Jiménez ${ }^{1}$}

\begin{abstract}
In fundamental physics, the Higgs field acts as a mechanism that generates mass in nonzero mass particles, thus traveling with limited mobility, not close to the speed of light. The field of economics has not developed an equivalent theory that would explain the so-called viscosities and rigidities that prevent the automatic adjustment of prices and the free mobility of factors. It is important to ask what that viscosity is and what characteristics it presents. Is it perhaps an unknown or ignored "economic field"?
\end{abstract}

Keywords: Higgs Field; rigidities; needs.

\section{Resumen}

En física fundamental el campo de Higgs actúa como un mecanismo que genera la masa de las partículas con masa no nula y, por tanto, con movilidad limitada no cercanas a la velocidad de la luz. Pero la economía no ha podido desarrollar una teoría equivalente que explique las supuestas viscosidades y rigideces que impedirían el ajuste automático de precios y la libre movilidad de los factores. Conviene preguntarse: que es esa viscosidad y que características presenta. ¿Acaso se trata de algún "campo económico" desconocido o ignorado?

Doi: http://dx.doi.org/10.15359/eys.23-54.4

This article corresponds to the translation of article http://dx.doi.org/10.15359/eys.23-54.2 published in this same issue of Journal Economía y Sociedad.

Received: 05-15-2018. Resent: 07-16-2018, 08-03-2018. Accepted 08-04-2018. Published 01-10-2018.

1 Doctor in Economics, Professor, School of Economics, Universidad Nacional, Costa Rica. Email address: hmoraj@gmail.com

Henry Mora Jiménez

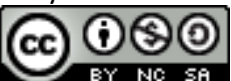

Revista Economía y Sociedad by Universidad Nacional is licensed under a CreativeCommons Reconocimiento-NoComercial- 
Palabras claves: Campo de Higgs; rigideces; necesidades.

\begin{abstract}
Resumo
Na física fundamental, o campo de Higgs atua como um mecanismo que gera a massa de partículas com massa não zero e, portanto, com mobilidade limitada, não próxima da velocidade da luz. Porém, a economia não conseguiu desenvolver uma teoria equivalente que explique as supostas viscosidades e rigidezes que impediriam o ajuste automático de preços e a livre mobilidade de fatores. É conveniente perguntar: qual é essa viscosidade e que características ela apresenta? Será que há algum "campo econômico" desconhecido ou ignorado?
\end{abstract}

Palavras-chave: Campo de Higgs, rigidez, necessidades

To some extent, orthodox, standard, or mainstream economics are like a particle without its Higgs field in physics (any analogy, useful or not, has its reservations and limitations). That is, we would be referring to a type of physics that has not been able to explain why certain elementary particles (fermions such as the electron, massive bosons such as $W$ and Z) have mass while others do not (photon and gluon); or even worse, a type of physics that has not even noticed the existence of this problem: "the problem of mass. ${ }^{2}$

In standard model physics, the Higgs field (and its respective boson) explains the mass of an electron and a small but crucial part of the mass of protons and neutrons (made up of quarks). Without this field, the universe would be very different from what we know and we probably would not exist. ${ }^{3}$

Theoretical physicists and mathematical economists have something in common: high esteem for "mathematical beauty", although in the case of physics, this type of beauty usually generates serious doubts if it has no support in reality or in experimentation results. In a similar way how particle physics is based on the idea of symmetry (a precise way of referring to mathematical beauty), standard economics has developed "limit concepts" (like the model of pure and perfect competition), in which the idea of perfection (and the option for mathematical elegance) also

\footnotetext{
${ }^{2}$ Without the Higgs field (according to the standard model), a subatomic particle such as the electron would not have mass, would move at the speed of light and atoms would not exist, nor would matter as we know it. Mutatis mutandis, in the neoclassical economic analysis we have the following problem: individuals are not consumers of flesh and bone (corporeal beings), but "a consistent set of maximizing preferences" (abstract mathematical entities or, metaphorically, "beings of light"). However, this amazing result does not even bother mathematical economists of the mainstream.

${ }^{3}$ We would not exist in the "neoclassical universe" of general equilibrium either, since we would be, as indicated in the footnote above, "beings of light".
}

122

Henry Mora Jiménez

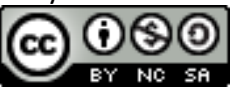

Revista Economía y Sociedad by Universidad Nacional is licensed under a CreativeCommons Reconocimiento-NoComercial- 
plays a central role, but in this case without the need to justify why symmetry is an adequate theoretical orientation ${ }^{4}$.

The Higgs field can be understood (at least metaphorically) as a viscous liquid (an effervescent sea) that gives mass to particles. Economists (especially the new Keynesians) have also resorted to the "viscous prices" heuristic to try to explain certain frictions, rigidities, anomalies, and market failures that would distance reality from the perfect foresight (omniscience), the perfect mobility of prices and factors, and the perfect substitution among production factors postulated by the standard general equilibrium model. In fundamental physics (particle physics) this "viscous field" would be the very same Higgs field (more precisely, the Higgs quantum field in the vacuum is the one that generates mass of nonzero mass particles); however, the field of economics has not been able to develop an equivalent theory that endogenously explains such viscosities or rigidities, which, it is assured, can limit or prevent the automatic adjustment of prices and the free mobility of factors. In addition, it is convenient to ask ourselves which entities exhibit this "viscosity" characteristic, goods prices, quantities, or some unknown or ignored "economic field".

In particle physics, viscosity is a property of the Higgs field, which, when interacting with the particles, causes some of them to gain mass (super concentrated energy), since it is precisely this interaction that creates (or not) the frictions and turbulences that exchange part of their energy into mass and reduce their speed allowing "fundamental forces" to act. The top quark, for example, is very massive, because its interaction with the Higgs field practically paralyzes it. In economics, on the contrary, this viscosity has been assigned to prices (or salaries) themselves. It is convenient to ask then: what is that viscosity or "molasses" that gives rigidity ("mass") to prices and salaries or prevents the perfect substitution between factors? The key to answering this question is prosaic, if you will: we are bodily beings with needs, a very different "field" from that of preferences.

Although some theoretical physicists do not consider the notion of Higgs field mathematically elegant or the corresponding mechanism by which mass is assigned to elementary particles (something that has to do with the "spontaneous rupture of symmetry"), none of them would currently dare to consider it as some sort of "anomaly" or "failure" in the standard model of particle physics, even after its experimental discovery in the Large Hadron Collider at CERN ${ }^{5}$. On

\footnotetext{
${ }^{4}$ Symmetries in the universe and the laws of physics do not find a similar justification in the world of economy and society, where hierarchy and asymmetry seem to be a more appropriate starting point.

${ }^{5}$ The Large Hadron Collider (LHC) is a particle accelerator and collider at the European Organization for Nuclear Research (CERN for its old name in French, Conseil Européen pour la Recherche Nucléaire), located near Geneva, on the Franco-Swiss border. It was designed to collide hadron beams, more precisely protons, its main purpose being to examine the validity and limits of the Standard Model.
}

Henry Mora Jiménez

Revista Economía y Sociedad by Universidad Nacional is licensed under a CreativeCommons Reconocimiento-NoComercial- 
the contrary, Higgs is a central part of this model, precisely the part that was missing and that was sought after for almost half a century ${ }^{6}$.

For this reason, we would like to suggest another line of research to study the "viscosities" and "rigidities" that are omnipresent in reality and that would subtract "symmetry" from the standard model of economy, aiming to explain these "viscosities" and "rigidities" from another perspective. In other words, we propose to explore what may be the "Higgs field" that economic theory lacks to explain "imperfect reality" not as failures or anomalies but as central aspects of market theory, moreover, a (more general) theory of economic coordination.

\section{Why do prices gain "rigidity"? The problem of needs}

In general equilibrium theory, the following statement is key:

The derivation of the general economic equilibrium exclusively from mercantile indicators implies that this general equilibrium is described exclusively in relative prices, which allows reducing the description of equilibrium to these mercantile indicators. (Hinkelammert, 2002, p. 148)

Indeed, prices calculated using the general equilibrium theory are exclusively relative, and to be able to have the possibility of calculating such prices, all prices of products and factors must be assumed to be completely variable, at least ranging between zero and some arbitrary positive amount. Specifically, complete salary variability must be assumed, which would allow to minimize the economic problem to a problem of determining relative prices and, therefore, reducing the economic decision to a problem of subjective preferences.

However, this assumption of absolute variability of wages also implies that human beings lack needs and only have likes. They choose between lamb and beef, but have no need for food. They choose between cotton and linen garments, but have no need for clothing, and so on.

Thanks to this reductionism, the economic problem of the neoclassical theory of general equilibrium is reduced, thus also decreasing the analysis of relative prices, preferences and certain restrictions ${ }^{7}$. It does not matter if the consumer's level of income allows him/her to survive. What matters only is how the consumer spends that income to optimize his/her

\footnotetext{
${ }^{6}$ Papers by Higgs and other prominent physicists (R. Brout and F. Englert among them) were published in 1964 . The Higgs boson was detected at CERN in July 2012 and confirmed in March 2013.

${ }^{7}$ It is basically the restriction of income, ignoring others that the same liberal thinkers proposed, such as: my freedom ends where the freedom of the other begins, my performance is limited by the general interest (Rousseau) or, in the market the actors must act in the framework of certain ethics (Hayek).
}

124

Henry Mora Jiménez

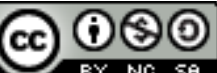

Revista Economía y Sociedad by Universidad Nacional is licensed under a CreativeCommons Reconocimiento-NoComercialCompartirlgual 4.0 Internacional License. Creado a partir de la obra en http://www.revistas.una.ac.cr/index.php/economia 
preferences, with which it is simply assumed that this level of income allows the consumer to satisfy his/her needs.

Viewing the human being as a person without needs but rather with preferences is an indispensable formal condition for the equations system to have a solution, since, otherwise, prices could not be quite variable.

Let's see the case of salary. Why can't salary be absolutely variable? Why can't it be zero or close to zero? The answer is obvious: the worker's survival could not be guaranteed in the market. Therefore, salary must have a lower limit that guarantees subsistence (unless it is a being without needs - kind of a "being of light".

But there is more, since, in that case, we would have two determinants of salary. On one hand, there would be equilibrium wages as calculated by the theory based on the interdependence of factors' supply and demand. On the other hand, we would have the determination of a positive minimum wage based on minimum subsistence. Consequently, if we introduce subsistence (needs) as the lower limit of salary in the equations' system of the equilibrium theory, equilibrium becomes contradictory, since it would then have two independent determinants of salary, and therefore, the system ceases to be consistent and there is no solution.

We cannot exclude the possibility that in a given economic situation there is not a consistent price system. Even perfect knowledge would not solve the problem, since when analyzed in terms of relative prices, the derived equilibrium is not feasible in general. It may or may not exist.

In short, due to the fact that there are human needs, an absolute determination of prices must be respected (salary in this case), and this consideration makes a price system derived only from relative prices inconsistent. Therefore, Sraffa (1983) is absolutely right when he considers wage, benefit, and rent of land as "distribution variables" rather than relative prices.

We face a similar problem if we take into consideration the necessary ecological balance, a longterm condition for human beings to satisfy their needs (in this case the limit is biophysical). Exclusively considering relative prices and the orientation of the human action for such prices does not exclude the possibility of destructing nature. This reminds us of Polanyi's warning: neither work (labor force) nor land (nature) are commodities in the strict sense, and we must refer to them as "fictitious commodities".

Thus, the market by itself does not present a tendency towards equilibrium, not even a consistent limit concept for such equilibrium. Considering the needs is what creates a "field" that makes prices of production factors "viscous". 


\section{References}

Hinkelammert, F. (2002). Crítica de la razón utópica. Desclée, Bilbao.

Polanyi, K. (1992). La gran transformación. Los orígenes políticos y económicos de nuestro tiempo. Fondo de Cultura Económica, Mexico.

Sraffa, P. (1983). La producción de mercancías por medio de mercancías. Oikos-tau S.A., Barcelona.

Tonelli, G. (2017). El nacimiento imperfecto de las cosas. La gran búsqueda de la partícula de Dios y la nueva física que cambiará el mundo. Los libros del lince, S.L., Barcelona. 